\title{
GREEN JOBS GREATION - MAIN ELEMENT IN THE IMPLEMENTATION OF BIOECONOMIC MECHANISMS
}

\author{
Florin-Alexandru Luca ${ }^{1}$, Gheorghe Epuran ${ }^{2 *}$, Claudia-Ioana Ciobanu ${ }^{3}$ \\ and Adrian V.Horodnic ${ }^{4}$ \\ 1), 3) „Gheorghe Asachi” Technical University, Iași, Romania \\ 2) „,Transilvania" University, Brașov, Romania, \\ 4) „, Grigore T. Popa” University of Medicine and Pharmacy, Iasi, Romania
}

Please cite this article as:

Luca, F.-A., Epuran, G., Ciobanu, C.I. and Horodnic, A.V., 2019. Green Jobs Creation - Main Element in the Implementation of Bioeconomic Mechanisms. Amfiteatru Economic, 21(50), pp. 60-74.

\section{Article History}

Received: 29 September 2018

Revised: 18 November 2018

Accepted: 16 December 2018

DOI: $10.24818 / \mathrm{EA} / 2019 / 50 / 60$

\begin{abstract}
Green jobs creation is the main element in the implementation of bioeconomy mechanisms along with other factors, such as gross domestic product (GDP), environmental protection and national security. The aim of this paper is to develop a profile of companies willing to create new jobs. Its objectives aim to identify the factors contributing to green jobs creation (objective 1) and to test the correlation of factors related to green jobs creation (objective 2 ). To reach the formulated objectives, the authors have used data extracted from Eurobarometer Flash 456 - SMEs, resource efficiency and green markets, representative for the 28 member states of the European Union that comprise interviews held between September 11 and 26 of 2017. For data analysis, first the descriptive methods, and then the multilevel logistic regression were used. The results show a higher likelihood that manufacturing companies with over 50 employees use personnel for green jobs, a turnover of over 500 million Euro, and an upward evolution of turnover. Novelty of the study lies in the development of an index for efficient use of resources comprising the implementation of a set of green measures that proved to be a significant instrument for new green jobs creation.
\end{abstract}

Keywords: green jobs, sustainable economic growth, Bioeconomy, sustainability, environmental behaviour.

JEL classification: Q01, O44, C30, Q56, Q57.

* Corresponding author, Gheorghe Epuran - epuran.gheorghe@unitbv.ro 


\section{Introduction}

Concern for environmental protection and the implementation of measures against climate change are issues that have been more often on the agenda of governmental institutions and researchers worldwide. Therefore, a large number of reports and academic studies have been written lately bringing arguments in favour of maintaining sustainable economic growth that would be based on environmental principles and be aimed at producing renewable biological resources and converting them into bioenergy and biotechnological products (Ronzon et al., 2017; Carus and Dammer, 2018). In this context, there has appeared a new paradigm of economic thought called bioeconomy that refers to sustainable development and smart use of technology (Voineagu, 2006; European Commission, 2012; Ronzon et al., 2017). The studies on human behaviour mechanisms show the likely effects of an economic model based on green jobs creation, the growth of gross domestic product (GDP), environmental protection and national security (Lehr, Lutz and Edler, 2012; Yi, 2013; Golden and Handfield, 2014; Dinu, 2008). Most studies and governmental reports pay a special attention to green jobs creation as they are involved in economic growth (OECD, 2011; Yi, 2013), but there are critics arguing that in some cases the main reason for green jobs creation is economic gain and not the environmental protection (Michaels and Murphy, 2009; Rabe, 2014; Bowen and Kuralbayeva, 2015). A current challenge for researchers has been to identify and understand the way in which the factors related to the creation of jobs may be controlled by the management or governmental institutions for developing new behavioural models. The study deals with this research issue.

The aim of this paper is to develop a profile of companies that are able to create new jobs. For this purpose, the literature in the field has been reviewed in order to identify the factors contributing to green jobs creation (objective 1). The outcomes of literature review have been used to formulate the research hypotheses in the methodology section. Testing the correlation of factors related to green jobs creation (Obiective 2) involves the study of data from secondary data, namely, the Eurobarameter Flash 456 - SMEs, resource efficiency and green markets (European Commission, 2018). Processing, analysis and interpretation of results was initially made using descriptive methods, and then using multilevel logistic regression. The article ends with the presentation of results.

\section{Literature review}

Environmental sustainable economic development and green job creation have been the main concern of researchers and governmental institutions. Therefore, there is a broad literature dealing with these two linked issues, and the findings of studies often report contradictory findings. First, it is due to the fact that the process of environmental economic development specific to bioeconomy is complex and long-term, and its results cannot be accurately foreseen (Mawby et al., 2016; Țugulea, 2017). Second, current economic studies (Wei, Patadia and Kammen, 2010; Golden and Handfield, 2014; Sillanpää and Ncibi, 2017) have succeeded in presenting only the influence of specific factors (for example, analysis of modification of GDP values) on economic development in terms of creation of new jobs or have examined just specific aspects of this phenomenon (for example, the area of green energy in relation with green economic growth).

Chapple et al. (2011, p.5) define green economy as "economic activity that reduces the consumption of energy and improves the quality of environment". Practically, green 
economic development refers to the implementation by companies of measures for effective use of resources (Cai et al., 2011; Martinez-Fernandez, Hinojosa and Miranda, 2010). Another broader perspective presents three main features that could describe green economic development: provides activity in sectors belonging to green industry, contributes to job creation and responds to strategic actions initiated by governmental policies ( $\mathrm{Yi}$, 2013). So, we may observe by analysing these definitions that there is a link between the two concepts, green economic development supporting the creation of green jobs.

From the perspective of international organisations initiating legislative proposals and economic policies, creation of green jobs is an important benefit obtained after the implementation of economic growth policies. International Labour Organization (ILO) considers that green jobs play the role of contributing to protection and renewal of the environment. Also, these jobs should have decent conditions, namely, ensure a proper salary, secure work conditions, and opportunities for career development (ILO, 2015). Providing these conditions extends the criteria for defining green jobs and contributes to reaching the important goal of governmental policies: poverty eradication (ILO, 2018). UECD reports (United Nations Environment Programme) underline the ambiguous nature of definitions provided by literature and stress out that technology is evolving and what was viewed as environmental a few years ago, might not be viewed as such now. In addition, criteria used to view a job as being green could be debatable depending on the level of economic and technological development of a specific country (Yi, 2013; Bowen and Kuralbayeva, 2015; OECD, 2017).

Wandzich and Płaza (2017) present the evolution over time of definitions for green jobs. Initially these played the role of protecting natural environment and were associated with green industry and bioeconomy. Now, there are low-carbon jobs, energy-efficiency job, and green jobs found along the logistic chain ensuring the production of green goods and services even if the job as such involves contact with non-environmental products and technologies. Therefore, the author presents green jobs as a generic term given to a wide range of jobs from different sectors of bioeconomy involving various work conditions and qualifications.

Most studies report a positive relation between green sustainable economic growth and job creation (Rabe, 2004; Yi, 2013). Models of sustainable economic development show a relation of interdependence between effective allocation of resources, sustainable economic growth, protection of environment and adoption of new green technologies and innovation Lehr, Lutz and Edler, 2012). The outcomes of this process have been intensely dealt with in the literature in the field and in economic policies as they contribute to the understanding of human behaviour mechanisms searching social welfare: increase of quality of life, protection of natural resources and biosphere, reduction of pollution, adaptation to climate change etc. (OECD, 2010; PEP, 2012; Pociovalișteanu et al., 2015; ILO, 2016; Dinu, Schileru and Atanase, 2012).

The theoretical model developed by Pociovălișteanu et al. (2015) describes a relation of interdependence between environmental protection and green economic growth through job creation and change in behaviour of consumption and production and sustainable development. Other studies on energy industry (Pollin et al., 2008; Apergis and Payne, 2010; Wei, Patadia and Kammen, 2010; Cetin and Egrican, 2011; Lehr, Lutz and Edler, 2012) support taking measures for more efficient use of resources, and implicitly, economic growth by creating green jobs. These studies make forecasts anticipating progress generating potential by increasing the number of jobs in specific sectors of industry. 
There are more sceptical authors who believe that programs aimed to stimulate the number of green jobs and green investments only play the role of destabilizing the current industry and mobilizing considerable funds towards other areas to the detriment of implementing current investment programs (Cai et al., 2011; Cock, 2014; Forstater, 2014; Rabe, 2014; Bowen and Kuralbayeva, 2015). High additional costs of green job creation (Bowen and Kuralbayeva, 2015), lack of data for correct forecasts (Deschênes, 2013; Wandzich and Płaza, 2017) or bulky legislation comprising vague terminology that may be difficult to put into practice (Morriss et al., 2009) are just a few areas of vulnerability reported by researchers that question the main role of green jobs for economic development.

To identify the behavioural models involved in the process of green production, it is first required to develop a profile of companies employing personnel for green jobs (Jijie and Bobâlcă, 2009). Numerous studies have analysed the causal relationships between the following factors and green jobs creation: type of business (production or services) (Russo and Fouts, 1997; Wei, Patadia and Kammen, 2010; Singh and Fers, 2011; Ronzon et al., 2017); turnover (Fierman, 1991; Koch and McGrath, 1995; Pujaria, Wrightb and Peattiec, 2003; Lehr, Lutz and Edler, 2012); turnover evolution (Russo and Fouts, 1997; Ronzon et al., 2017). In other studies, green jobs are associated with traditional and big companies (Martinez-Fernandez, Hinojosa and Miranda, 2010). Other studies report a relation between company performance operating in the environmental sector and its size (Arda, Bayraktar and Tatoglu, 2018). Accordingly, considering that company performance contributes to the creation of green jobs (Pujaria, Wrightb and Peattiec, 2003; Lehr, Lutz and Edler, 2012).

Studies investigating current jobs in green industries report that it is more likely for companies operating in $\mathrm{B} 2 \mathrm{~B}$ (business-to-business), selling goods and services to other businesses, than for companies selling to end-users (B2C: business-to-consumer) to employ personnel for green operations. The research underlines the fact that the increase of technological development imposes the creation of new economic models and implicitly a higher openness towards new ways of selling products (Ronzon et al., 2017; Wandzich and Płaza, 2017).

The reports of international organisations promoting sustainable economic development and adoption of bioeconomy principles include accurate data on the results obtained in countries with a higher level of development, such as Germany, Sweden, Norway, France, Austria. These countries have already implemented programs for the labour market aimed to create green jobs that generated profitability for the employing company (Ge and Zhi, 2016; Altenburg and Assmann, 2017; Ronzon et al. 2017; OECD, 2017). Other studies support the idea that new technologies adoption may be easier to implement in less developed than in developed countries that already have a strong industry, which would be costlier to restructure, and have a workforce, which, in some cases, could be more difficult to requalify (Bowen and Kuralbayeva, 2015; Wandzich and Płaza, 2017). There are other views supporting also other factors for evaluating the opportunities for green jobs creation depending on their belonging to a more or less developed state. These studies report the type of industry (for example, green energy industry in more developed states is linked to a higher number of new jobs) or level of development and implementation of governmental environmental policies (for example, a less developed state with an adequate legislation providing tax facilities has better chances to create green jobs) (Pollin et al., 2008; Wei, Patadia and Kammen, 2010; Cai et al., 2011).

Vol. $21 \cdot$ No. $50 \cdot$ February 2019 


\section{Methodology}

In the methodological approach we considered the view of some authors (Russo and Fouts, 1997) who observe that the aligning of production standards to requirements of environmental protection is a complex process that involves, besides the above mentioned factors, (green economic growth, sector, company size, company age, turnover and turnover evolution, type of client for sale of goods or services, and the country) also the factors related to the implementation of a new organizational culture and a new human resources and information management system.

The research question aims to identify and understand the way in which the factors related to creation of jobs may be controlled by the management or governmental institutions for developing new behavioural models. Therefore, the aim of the study is to develop a profile of companies able to create new jobs and it aims to reach the following objectives:

- Objective 1: to identify the factors contributing to green jobs creation;

- Objective 2: to test the correlation of factors related to green jobs creation.

The literature review of previous studies showed a series of factors related to green jobs creation contributing to reaching the first objective. The second objective includes testing the following hypotheses formulated based on the review of the literature in the field (for example, Fierman, 1991; Koch and McGrath, 1995; Russo and Fouts, 1997; Pujaria, Wrightb and Peattiec, 2003; Wei, Patadia and Kammen, 2010; Singh and Fers, 2011; Lehr, Lutz and Edler, 2012; Ge and Zhi, 2016; OECD, 2017; UNEP, 2017).

- Hypothesis 1: The more resource efficiency actions a company is taking, the more likely it is for employees to have a green job.

- Hypothesis 2: Green employment varies by company features (sector of activity, company size, company age, turnover, turnover evolution). Green employment is more common in: $H 2 a$ : industry; $H 2 b$ : large firms; $H 2 c$ : older firms; $H 2 d$ : companies with high turnover; $H 2 e$ : companies with positive turnover evolution.

- Hypothesis 3: Companies selling products or services to other companies (B2B) are more likely to have employees working in green jobs.

- Hypothesis 4: Companies in developed EU countries are more likely to have employees working in green jobs than those in less developed EU countries.

In order to evaluate the proposed hypotheses, this study uses the Flash Eurobarometer 456 - SMEs, resource efficiency and green markets (European Commission, 2018), conducted between $11^{\text {th }}$ and $26^{\text {th }}$ of September 2017. Alongside other countries, the survey was carried out as well in the 28 Member states of the European Union. For the purpose of this study, the selected sample comprises active businesses employing one or more people in EU28. Across EU28, 13,117 interviews were conducted with the management of investigated companies. According to the Flash Eurobarometer technical specifications, the sample was selected from an international business database (where necessary, additional sample from local sources was added) and covers both SMEs and large companies (European Commission, 2017). In this study, considering the particularities of multi-level logistic regression, the dependent variable measures whether companies have full time 
employees working in green jobs (at least some of the time) and is based on a dummy variable with recoded value 1 if the company has employees in a green job and 0 otherwise.

The "green job" was defined as "a job that directly deals with information, technologies, or materials that preserves or restores environmental quality. This requires specialised skills, knowledge, training, or experience (e.g. verifying compliance with environmental legislation, monitoring resource efficiency within the company, promoting and selling green products and services)" (European Commission, 2017).

To analyse $H_{1}$ regarding whether the likelihood to have employees in a green job is associated with resource efficiency oriented firms, a Resource Efficiency Index is constructed. The index comprise the number of actions companies are taking to be more resource efficient and is measures on a scale from 1 to 4 (where 1 means no actions and 4 means many actions). The list of actions considered to be more resource efficient included: a) Saving water; b) Saving energy; c) Using predominantly renewable energy (e.g. including own production through solar panels, etc.); d) Saving materials; e) Minimising waste; f) Selling scrap material to another company; g) Recycling, by reusing material or waste within the company; h) Designing products that are easier to maintain, repair or reuse; i) Other action to promote resource efficiency. The higher the index value, the more resource efficient is the firm.

The other independent variables used to analyse which companies are more likely to have employees in a green job $(H 2-H 4$, according to results in previous studies, Fierman, 1991; Koch and McGrath, 1995; Russo and Fouts, 1997; Pujaria, Wrightb and Peattiec, 2003; Wei, Patadia and Kammen, 2010; Singh and Fers, 2011; Lehr, Lutz and Edler, 2012; Ge and Zhi, 2016; OECD, 2017) are: sector of activity, company size, company age, turnover, and turnover evolution, type of client for selling products or services, and country.

To analyse the results, we firstly used a descriptive analysis by country, and secondly, a multi-level logistic regression analysis. The multi-level logistic regression was employed due to the hierarchical nature of the data, namely companies $(i)$ nested within countries $(j)$. Considering the particularities of this study, the analysis is conducted according to the following model specification (Steele, 2009):

$\log \left(\frac{\pi_{i j}}{1-\pi_{i j}}\right)=\beta_{0}+\beta_{1} X_{i j}+u_{j}$

Where:

$\pi_{i j}$ - the likelihood to have employees in a green job;

$\beta_{0}$ - the overall intercept;

$\beta_{1}$ - the cluster specific effect;

$X_{i j}$ - the vector with explanatory variables;

$u_{j}$ - the group (random) effect.

For the descriptive analysis, likewise previous studies using similar data (Williams and Horodnic, 2015a; 2015b; 2016; 2017, 2018a, 2018b; Horodnic and Williams, 2018; Horodnic, Mazilu and Oprea, 2018; Horodnic et al., 2018; Luca et al., 2018) and as recommended in the Eurobarometer methodology, we used the sampling weighting scheme. 
In a first stage, the multivariate analysis is here conducted using crude data and without weighting scheme. However, in the second stage weighting scheme is used as well as imputations for missing data to demonstrate the robustness of the findings. The results are also used to graphically display whether significant variations between countries exist in the likelihood to have green employment. The data analyis presented in the tables was carried out using STATA software, version 14.

\section{Results and discussions}

Overall, $40 \%$ of companies in EU28 have at least one full time employee working in green jobs at least some of the time. As table no. 1 displays, the distribution of green employment is uneven across countries. For instance, green employment is more common in Latvia (64\% of all companies having at least one full time employee working in green jobs at least some of the time), Croatia (58\%) and Italy (57\%) and less likely in Malta (7\%) and Estonia (15\%).

Table no 1: Green employment in EU28, by country $(N=13,117)$

\begin{tabular}{|c|c|c|c|c|c|c|c|}
\hline \multirow{3}{*}{$\begin{array}{l}\text { Region/ } \\
\text { Country }\end{array}$} & \multicolumn{3}{|c|}{ Employees in green jobs } & \multirow{3}{*}{$\begin{array}{l}\text { Region/ } \\
\text { Country }\end{array}$} & \multicolumn{3}{|c|}{ Employees in green jobs } \\
\hline & $\begin{array}{c}\text { At least } \\
\text { one }\end{array}$ & None & $\begin{array}{l}\text { Don't } \\
\text { know }\end{array}$ & & $\begin{array}{c}\text { At least } \\
\text { one }\end{array}$ & None & $\begin{array}{l}\text { Don't } \\
\text { know }\end{array}$ \\
\hline & $(\%)$ & $(\%)$ & $(\%)$ & & $(\%)$ & $(\%)$ & $(\%)$ \\
\hline$E U 28$ & 40 & 54 & 6 & & & & \\
\hline Latvia & 64 & 27 & 9 & Netherlands & 35 & 59 & 6 \\
\hline Croatia & 58 & 34 & 8 & Romania & 35 & 56 & 9 \\
\hline Italy & 57 & 42 & 1 & Belgium & 32 & 59 & 9 \\
\hline Sweden & 56 & 37 & 7 & Denmark & 32 & 67 & 1 \\
\hline Slovakia & 56 & 36 & 8 & France & 29 & 68 & 3 \\
\hline Finland & 53 & 43 & 4 & United Kingdom & 26 & 63 & 11 \\
\hline Portugal & 50 & 46 & 4 & Slovenia & 26 & 71 & 3 \\
\hline Spain & 49 & 45 & 6 & Bulgaria & 22 & 62 & 16 \\
\hline Greece & 46 & 50 & 4 & Czech Republic & 21 & 69 & 10 \\
\hline Luxembourg & 41 & 55 & 4 & Hungary & 21 & 69 & 10 \\
\hline Austria & 40 & 50 & 10 & Lithuania & 19 & 77 & 4 \\
\hline Germany & 38 & 53 & 9 & Cyprus & 17 & 80 & 3 \\
\hline Poland & 38 & 53 & 9 & Estonia & 15 & 82 & 3 \\
\hline Ireland & 36 & 48 & 16 & Malta & 7 & 93 & 0 \\
\hline
\end{tabular}

Source: Own calculations using STATA software based

on Flash Eurobarometer 456 dataset - European Commission, 2018

To analyse which type of firms are more likely to be associated with green employment, table no. 2 reports the results of a multi-level logistic regression analysis. Model 1 in table 2 reveals that there is a positive relationship between green employment and Resource Efficiency Index. The higher the index value (the more resource efficiency actions a company is taking), the higher the likelihood to have employees in a green job (confirming $\mathrm{Hl}$ ).

Model 1 in table no. 2 also reveals that green employment is more common for certain categories of firms. Companies in industry sector are more likely while those in services sector are less likely to have employees in a green job than companies in manufacturing sector (confirming $\mathrm{H} 2 \mathrm{a}$ ). Similarly, not only are larger companies (50 employees or more) 
more likely to have employees in a green job (confirming $H 2 b$ ), but so too are those with a turnover higher than 50 million euros (confirming $H 2 d$ ). Indeed, companies registering a decreased turnover over the past two years are less likely to participate in green employment than companies who increased their turnover over the past two years (confirming $\mathrm{H} 2 \mathrm{e}$ ). However, no statistically significant association was identified between green employment and the year when the company was established (refuting $\mathrm{H2c}$ ). Similarly, according to Model 1 in table no. 2, no strong association was identified between green employment and the type of client for selling products or services (refuting H3). In addition, Model 2 and Model 3 in table no. 2 reveal that the same results are obtained if running the regression by using the weighting scheme or imputations for missing data).

Table no. 2: Multilevel logistic regressions of the likelihood to have at least one full time employee in a green job

\begin{tabular}{|c|c|c|c|c|c|c|c|c|c|c|c|c|}
\hline \multirow[b]{3}{*}{ Variables } & \multicolumn{4}{|c|}{ Model 1} & \multirow{2}{*}{\multicolumn{4}{|c|}{$\begin{array}{l}\text { Model } 2 \\
\text { sing weighting } \\
\text { scheme }\end{array}$}} & \multirow{2}{*}{\multicolumn{4}{|c|}{\begin{tabular}{|c|} 
Model 3 \\
Imputed data
\end{tabular}}} \\
\hline & \multirow[b]{2}{*}{$\beta$} & \multirow{2}{*}{\multicolumn{2}{|c|}{$\begin{array}{l}\mathrm{Se} \\
(\beta) \\
\end{array}$}} & \multirow[b]{2}{*}{$\begin{array}{c}\text { Exp } \\
(\beta) \\
\end{array}$} & & & & & & & & \\
\hline & & & & & $\beta$ & \multirow[b]{2}{*}{ ** } & $\begin{array}{l}\mathrm{Se} \\
(\beta) \\
\end{array}$ & $\begin{array}{c}\text { Exp } \\
(\beta) \\
\end{array}$ & $\beta$ & \multicolumn{2}{|r|}{$\begin{array}{l}\mathrm{Se} \\
(\beta) \\
\end{array}$} & $\begin{array}{c}\text { Exp } \\
(\beta) \\
\end{array}$ \\
\hline $\begin{array}{c}\text { Resource Efficiency } \\
\text { Index }\end{array}$ & 0,556 & *** & 0,023 & 1,744 & 0,556 & & 0,043 & 1,744 & 0,559 & $* * *$ & 0,023 & 1,749 \\
\hline \multicolumn{13}{|c|}{\begin{tabular}{|l|} 
Sector (CG: Manufacturing) \\
\end{tabular}} \\
\hline Retail & $-0,110$ & \begin{tabular}{|l|}
$*$ \\
\end{tabular} & 0,059 & 0,896 & $-0,110$ & $*$ & 0,061 & 0,896 & $-0,115$ & $*$ & 0,059 & 0,892 \\
\hline Services & $-0,175$ & ***** & 0,059 & 0,839 & $-0,175$ & **** & 0,051 & 0,839 & $-0,166$ & $* * *$ & 0,058 & 0,847 \\
\hline Industry & 0,185 & ***** & 0,066 & 1,203 & 0,185 & $* *$ & 0,074 & 1,203 & 0,194 & **** & 0,065 & 1,214 \\
\hline \multicolumn{13}{|c|}{ Company size (CG: 1-9 employees) } \\
\hline $10-49$ & 0,071 & & 0,056 & 1,074 & 0,071 & & 0,056 & 1,074 & 0,068 & & 0,055 & 1,070 \\
\hline $50-249$ & 0,471 & **** & 0,075 & 1,602 & 0,471 & *** & 0,106 & 1,602 & 0,482 & $* * *$ & 0,071 & 1,619 \\
\hline 250 or more & 0,907 & ***** & 0,111 & 2,477 & 0,907 & **** & 0,137 & 2,477 & 0,885 & **** & 0,107 & 2,422 \\
\hline \multicolumn{13}{|c|}{ Company established (CG: before 1 January 2010) } \\
\hline 1 Jan. 2010-1 Dec. 201 & 0,078 & & 0,078 & 1,082 & 0,078 & & 0,074 & 1,082 & 0,067 & & 0,077 & 1,069 \\
\hline 1 Jan. 2013-1 Jan. 2017 & 0,053 & & 0,076 & 1,054 & 0,053 & & 0,099 & 1,054 & 0,040 & & 0,076 & 1,041 \\
\hline After 1 Jan. 2017 & 0,089 & & 0,254 & 1,093 & 0,089 & & 0,266 & 1,093 & 0,103 & & 0,257 & 1,108 \\
\hline \multicolumn{13}{|c|}{ Turnover last year (CG: 100,000 $€$ or less) } \\
\hline$>100,000$ to $500,000 €$ & 0,067 & & 0,070 & 1,069 & 0,067 & & 0,096 & 1,069 & 0,066 & & 0,070 & 1,068 \\
\hline$>500,000$ to 2 mil. $€$ & 0,052 & & 0,077 & 1,053 & 0,052 & & 0,106 & 1,053 & 0,057 & & 0,078 & 1,058 \\
\hline$>2$ to 10 mil. $€$ & 0,036 & & 0,088 & 1,037 & 0,036 & & 0,130 & 1,037 & 0,024 & & 0,086 & 1,024 \\
\hline$>10$ to 50 mil. $€$ & 0,096 & & 0,106 & 1,101 & 0,096 & & 0,138 & 1,101 & 0,100 & & 0,103 & 1,106 \\
\hline$>50$ mil. $€$ & 0,415 & **** & 0,142 & 1,514 & 0,415 & $* *$ & 0,196 & 1,514 & 0,444 & **** & 0,140 & 1,558 \\
\hline Not applicable/DK ${ }^{1}$ & $-0,038$ & & 0,087 & 0,963 & $-0,038$ & & 0,117 & 0,963 & $-0,052$ & & 0,085 & 0,950 \\
\hline \multicolumn{13}{|c|}{ Turnover evolution over the past two years (CG: Increased) } \\
\hline Decreased & $-0,132$ & $* *$ & 0,061 & 0,876 & $-0,132$ & $* *$ & 0,057 & 0,876 & $-0,141$ & *** & 0,061 & 0,869 \\
\hline Remained unchanged & $-0,059$ & & 0,049 & 0,943 & $-0,059$ & & 0,058 & 0,943 & $-0,066$ & & 0,050 & 0,936 \\
\hline Not applicable /DK ${ }^{1}$ & $-0,107$ & & 0,110 & 0,899 & $-0,107$ & & 0,137 & 0,899 & $-0,126$ & & 0,112 & 0,881 \\
\hline \multicolumn{13}{|c|}{ Selling products or services } \\
\hline \multicolumn{13}{|c|}{ Directly to consumers (CG: No) } \\
\hline Yes & $-0,045$ & & 0,048 & 0,956 & $-0,045$ & & 0,066 & 0,956 & $-0,050$ & & 0,048 & 0,952 \\
\hline \multicolumn{13}{|c|}{ To other companies (CG: No) } \\
\hline Yes & 0,001 & & 0,053 & 1,000 & 0,001 & & 0,056 & 1,000 & $-0,005$ & & 0,052 & 0,995 \\
\hline
\end{tabular}




\begin{tabular}{|c|c|c|c|c|c|c|c|c|c|c|c|c|}
\hline & \multicolumn{3}{|c|}{ Model 1 } & \multicolumn{3}{c|}{ Model 2 } & \multicolumn{3}{c|}{ Model 3 } \\
\hline & \multicolumn{9}{|c|}{$\begin{array}{c}\text { Using weighting } \\
\text { scheme }\end{array}$} & \multicolumn{5}{c|}{ Imputed data } \\
\hline
\end{tabular}

Notes: Significant at $* * * \mathrm{p}<0.01, * * \mathrm{p}<0.05, * \mathrm{p}<0.1$; Coefficients are compared to the benchmark category, shown in brackets; ${ }^{1}=$ Don ${ }^{`}$ know .

Source: Own calculations based on Flash Eurobarometer 456 data set - European Commission, 2018

To determine whether significant variations between countries exist in the propensity to have green employment, after controlling for variables in Model 1, figure no. 1 displays the residual country effects.

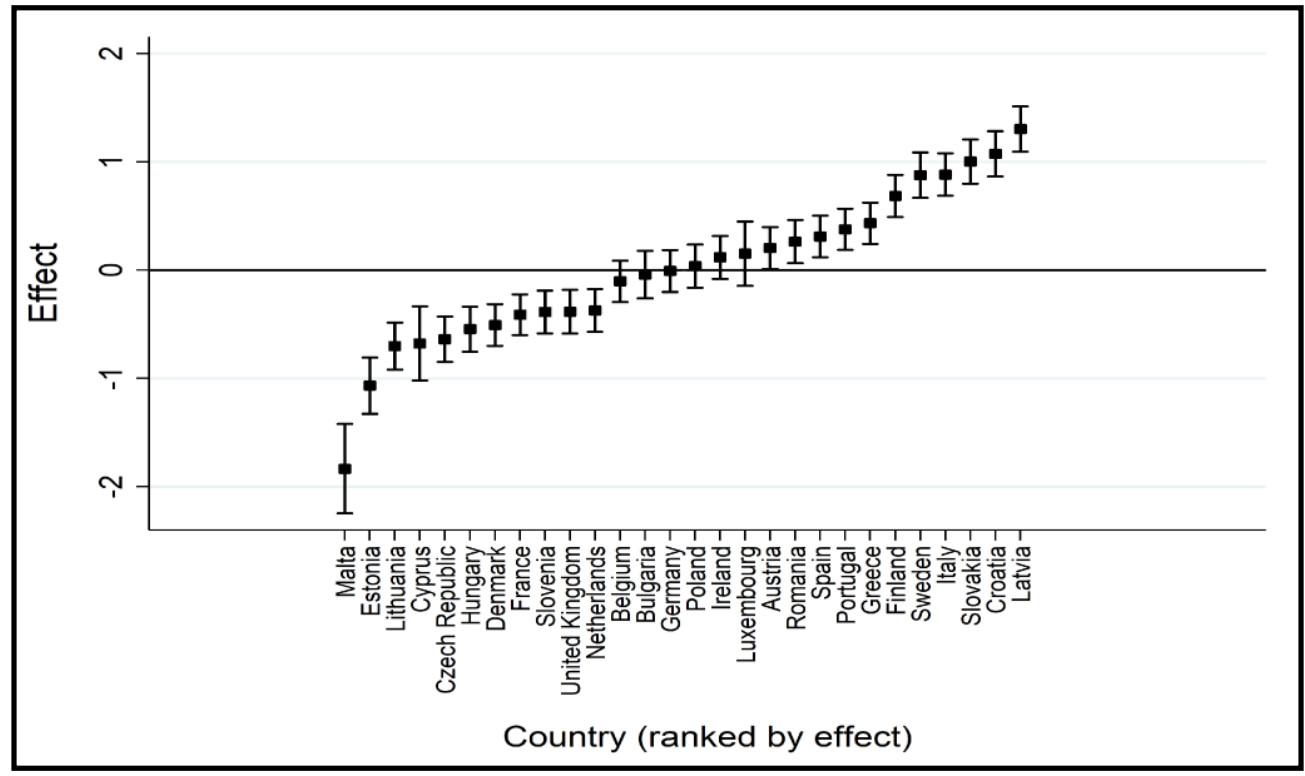

Figure no. 1: Cross-national variations in green employment in EU28: residual country effects within a $95 \%$ confidence interval $(N=11,824)$

Source: Own calculations using STATA software based

on Flash Eurobarometer 456 data set - European Commission, 2018

A country whose confidence interval (5\% significance level) does not overlap the line at zero differs significantly from the EU28 average. For instance, at the lower end, companies in Malta, Estonia and Lithuania have a significantly lower propensity to have employees in a green job. At the upper end, companies in Latvia, Croatia, Slovakia, Italy, Sweden and Finland have a significantly higher propensity to have employees in a green job. Figure 1 
therefore reveals that not always companies in affluent countries (e.g., Germany, United Kingdom, France) have significantly higher propensity to have employees working in green jobs than those in less affluent countries (refuting $H 4$ ).

Table no. 3 presents the summary of the results of hypotheses testing

Table no. 3: Results of hypothese testing

\begin{tabular}{|l|c|}
\hline \multicolumn{1}{|c|}{ Hypothesis } & Result \\
\hline $\begin{array}{l}\text { H1. The more resource efficiency actions a company is taking, the more } \\
\text { likely it is for employees to have a green job. }\end{array}$ & Confirmed \\
\hline $\begin{array}{l}\text { H2. Green employment varies by company features (sector of activity, } \\
\text { company size, company age, turnover, turnover evolution). }\end{array}$ & $\begin{array}{c}\text { Partially } \\
\text { confirmed }\end{array}$ \\
\hline $\begin{array}{l}\text { H3. Companies selling products or services to other companies (B2B) are } \\
\text { more likely to have employees working in green jobs. }\end{array}$ & Rejected \\
\hline $\begin{array}{l}\text { H4. Companies in developed EU countries are more likely to have } \\
\text { employees working in green jobs than those in less developed EU countries. }\end{array}$ & Rejected \\
\hline
\end{tabular}

The profile of companies operating in the green sector is another issue investigated in this study as the variables used for this profile reflect concrete aspects that may be quantified by company managers who have to adopt a new bioeconomic behavioural model in developing their strategies. Therefore, manufacturing big companies (over 50 employees) with a positive turnover evolution are more likely to employ personnel for green jobs. Also, the study has confirmed the results of other studies linking green jobs creation with goods manufacturing sector to the detriment of service companies (Russo and Fouts, 1997; Wei, Patadia and Kammen, 2010; Singh and Fers, 2011; Ronzon et al., 2017). Although the company age on a market is a profitability index, this study has not found a direct link between company age and likelihood of green jobs creation.

Modern model of sales operations management led to a natural separation of companies: B2B interacting with legal entities (other companies) and companies selling services directly to consumers (end users). Even if some studies report a higher likelihood for B2B to have green operations and employ personnel for green jobs (Ronzon et al., 2017; Wandzich and Płaza, 2017), this study has not confirmed this hypothesis. The fact that B2B and $\mathrm{B} 2 \mathrm{C}$ companies have similar behaviour when they take decisions regarding green operations, including green jobs creation, may be explained by recent high mediatisation of governmental policies stimulating green behaviour or increased understanding of importance of green practices by direct experience or market studies.

In what regards the employing company, the findings show that companies in developed countries (e.g. Germany, Great Britain, France) do not always have significantly higher likelihood to have green jobs personnel compared to less affluent companies. This result confirms the findings of studies supporting the opportunity of green jobs creation in less developed countries lacking an already functioning industrial infrastructure (Bowen and Kuralbayeva, 2015; Wandzich and Płaza, 2017), and studies considering other factors, such as type of industry or level of implementation of governmental green policies (Pollin et al., 2008; Wei, Patadia and Kammen, 2010; Cai et al., 2011).

\section{Conclusions}

Once new jobs have been created, there takes place an ecologisation of processes of production and consumption leading to higher quality of life and changed consumption 
behaviour of the population. This study investigates the implications of green jobs creation in employing companies of the European Union (EU28)

From a theoretical perspective, the conducted analysis was aimed to clarify specific divergent vies in the literature in the field dealing with the impact of green jobs creation in the context of inherent changes occurring in a world under a process of transition towards implementation of principles of economic growth specific to bioeconomy. Efficient use of resources has been the main recommendation given by researchers and institutions initiating green public policies and is most commonly accompanied by economic growth and profitability. In this study, we have analysed the likelihood of a relation between green jobs and efficient use of resources, and implicitly economic progress. The obtained results are similar to the results reported in previous studies (Rabe, 2004; Luca and Crețescu, 2010; Lehr, Lutz and Edler, 2012; Yi, 2013; Pociovălișteanu et al., 2015). Moreover, the study suggests and develops an index for efficient use of resources that includes the implementation ofa set of green measures. The literature review also underlines a lack of uniform methods for measuring and forecasting the effects of green jobs creation. The instrument used in this study comprises the variables identifies in earlier studies and that have been validated by the decision-makers in companies opearting in 28 European countries. Also, the implementation of this instrument may contribute to solving a controversial issue reported by the literature in the field: lack of uniform methods for measuring and forecasting the effects of green jobs creation. (Pollin et al., 2008; Bowen and Kuralbayeva, 2015; Altenburg and Assmann, 2017).

While there are voices supporting that profitability and economic growth may be achieved by unjustified consumption of natural resources and environmental protection is an expense for companies to the detriment of profitability, this study confirms what most previous studies claim, namely, the fact that efficient use of resources and green jobs creation bring profit to companies, and implicitly lead to higher turnover and its positive evolution also for companies in less developed European countries.

The practical contributions of the study refer to underlining measures accepted at the European level that may be implemented by companies to protect the environment. The profile of companies employing personnel for green jobs is extremely practical as it comprises quantifiable variables that may be used by managers of companies in the green sector. Also, governmental institutions and reserchers could use them to write country reports and studies analysing the behaviour of companies in Europe employing personnel for green jobs.

The paper discusses a current issue stirring the interest of researchers and decision-makers initiating governmental policies, which leads to an increasing number of studies and reports on the implications of green jobs creation in the context of transition to bioeconomy. Lack of a unifies viewpoint on the methods for defining and measuring this concept is a limitation applicable to this study. Another limitation of this study is lack of longitudinal data allowing us to test a relation of causal type. Although the study provides input on the relation among the variables, the analysis is still of descriptive type

The analysed issue, green jobs creation, is the main element for the implementation of bioeconomic mechanisms together with other factors, such as increase of gross domestic product (GDP), environmental protection and natural security. For a broader view on the implications of behavioural variables on the process of transition to bioeconomy, future studies could test the links among these factors and variables describing the profile of 
companies employing personnel involved in green operations that have been confirmed by this study: manufacturing big companies, with effective use of resources, with over 50 employees, a turnover over 500 million Euro, and a positive evolution of turnover irrespective of the type pf operations (B2B or B2C) or country of origin.

\section{References}

Altenburg, T. and Assmann, C., 2017. Green Industrial Policy. Concept, Policies, Country Experiences. [pdf] Geneva, Bonn: UN Environment, German Development Institute. Available at: <http://wedocs.unep.org/bitstream/handle/20.500.11822/22277/Green_ industrial_policy.pdf?isAllowed=y\&sequence=1> [Accessed 18 July 2018].

Apergis, N. and Payne, J.E., 2010. Renewable energy consumption and economic growth: evidence from a panel of OECD countries. Energy Policy, 38(1), pp.656-60.

Arda, O.A., Bayraktar, E. and Tatoglu, E., 2018. How do integrated quality and environmental management practices affect firm performance? Mediating roles of quality performance and environmental proactivity. Business Strategy and Environment, [e-journal], pp.1-15. https://doi.org/10.1002/bse.2190.

Bowen, A. and Kuralbayeva, K., 2015. Looking for green jobs: the impact of green growth on employment. [pdf] London: Grantham Research Institute on Climate Change and the Environment \& London School of Economics and Political Science. Available at: <http://www.lse.ac.uk/GranthamInstitute/wp-content/uploads/2015/03/Looking-forgreen-jobs_the-impact-of-green-growth-on-employment.pdf> [Accessed 28 July 2018].

Cai, W., Wang, C., Chen, J. and Wang, S., 2011. Green economy and green jobs: Myth or reality? The case of China's power generation sector. Energy, [e-journal] 36(10), pp.5994-6003. https://doi.org/10.1016/j.energy.2011.08.016.

Carus, M. and Dammer, L., 2018. The Circular Bioeconomy-Concepts, Opportunities, and Limitations. Industrial Biotechnology, [e-journal] 14(2), pp.83-91. https://doi.org/ 10.1089/ind.2018.29121.mca.

Cetin, M. and Egrican, N., 2011. Employment impacts of solare nergy in Turkey. Energy Policy, 39(11), pp.7184-90.

Chapple, K., Kroll, C., Lester, T.W. and Montero, S., 2011. Innovationin the green economy: anextension of regionalin novation system model? Economic Development Quarterly, 25(1), pp.5-25.

Cock, J., 2014. The 'Green Economy': A Just and Sustainable Development Path or a 'Wolf in Sheep's Clothing'?, Global \& Labour Journal, 5(1), pp.21-44.

Deschênes, O., 2013. Green jobs. Policy Paper. Bonn: Institute for the Study of Labor.

Dinu, V., 2008. The ethical dimension of business. Amfiteatru Economic, 10(23) pp.7-8.

Dinu, V., Schileru, I. and Atanase, A., 2012. Attitude of romanian consumers related to products' ecological labeliling. Amfiteatru Economic, 14(31) pp.8-24.

European Commission, 2012. Innovating for Sustainable Growth: a Bioeconomy for Europe (Report). Brussels: European Commission.

European Commission, 2017. Flash Eurobarometer 456. Small and Medium Enterprises, Resource Efficiency and Green Markets (Report). Brussels: European Commission. 
European Commission, 2018. Flash Eurobarometer 456. Small and Medium Enterprises, Resource Efficiency and Green Markets. TNS Political \& Social [producer]. Cologne: GESIS Data Archive. 10.4232/1.12966.

Fierman, J., 1991. The big muddle in green marketing. Fortune,123, pp.91-101.

Forstater, M., 2014. Green jobs: addressing the critical issues surrounding the environment, workplace, and employment. International Journal of Environment, Workplace and Employment, 1(1), pp. 53-61.

Ge, Y. and Zhi, Q., 2016. Literature Review: The Green Economy, Clean Energy Policy and Employment. Energy Procedia, 88, pp.257-64.

Golden, J.S. and Handfield, R., 2014. The Emergent Industrial Bioeconomy. Industrial Biotechnology, [e-journal] 10(6), pp.371-375. https://doi.org/10.1089/ind.2014.1539.

Horodnic, A.V. and Williams, C.C., 2018. Informal payments by patients for health services: prevalence and determinants. Service Industries Journal, 38(11-12), pp.841-55.

Horodnic, A.V., Apetrei, A., Luca, F.A. and Ciobanu, C.I., 2018. Rating healthcare services: consumer satisfaction vs. health system performance. Service Industries Journal, 38(13-14), pp.974-94.

Horodnic, A.V., Mazilu, S. and Oprea, L., 2018. Drivers behind widespread informal payments in the Romanian public health care system: From tolerance to corruption to socio-economic and spatial patterns. International Journal of Health Planning and Management, 33(2), pp.597-611.

International Labour Organization (ILO), 2015. Green Jobs. [pdf] Available at: <http://www.ilo.org/wcmsp5/groups/public/---dgreports/---integration/documents/ genericdocument/wcms_561751.pdf>[Accessed 18 July 2018].

International Labour Organization (ILO), 2016. Progress Report. [pdf] Available at: <http://www.ilo.org/wcmsp5/groups/public/---ed_emp/---emp_ent/documents/ publication/wcms_502730.pdf> [Accessed 18 July 2018].

International Labour Organization (ILO), 2018. What is a Green Job? [online] Available at: <http://www.ilo.org/global/topics/green-jobs/news/WCMS_220248/lang--en/ index.htm> [Accessed 15 July 2018].

Jijie, T. and Bobâlcă, C., 2009. Beyond Credibility: Scale Development for Measuring a Candidate's Profile. Transformations in Business \& Economics, 8(3), pp.244-54.

Koch, M.J. and McGrath, R.G., 1995. Improving labor productivity: Human resource management policies do matter. Strategic Management Journal, 17(5), pp.335-54.

Lehr, U., Lutz, C. and Edler, D., 2012. Green jobs? Economic impacts of renewable energy in Germany. Energy Policy, [e-journal] 47(1), pp.358-64. https://doi.org/10.1016/ j.enpol.2012.04.076.

Luca, F.A., Ciobanu, C.I., Andrei, A.G. and Horodnic, A.V., 2018. Raising Awareness on Health Impact of the Chemicals Used in Consumer Products: Empirical Evidence from East-Central Europe. Sustainability, [e-journal] 10(1), pp.1-15. https://doi.org/10.3390/ su10010209.

Luca, F.A. and Creţescu, I., 2010. Management of the northern-eastern region of Romania viewed from the perspective of ecotourism development. Environmental Engineering and Management Journal, 9(1), pp.153-157. 
Martinez-Fernandez, C., Hinojosa, C. and Miranda, G., 2010. Green jobs and skills: the local labour market implications of addressing climate change. [pdf] Available at: <www.oecd.org/dataoecd/54/43/44683169.pdf?contentId=44683170> [Accessed 25 July 2018].

Mawby, R.I., Tecău, A., Constantin, C.P., Chițu, I.B. and Tescașiu, B. 2016. Addressing the Security Concerns of Locals and Visitors for the Sustainable Development of Tourist Destinations. Sustainability, [e-journal] 8(6), pp.1-12. https://doi.org/ 10.3390/su8060524.

Michaels, R. and Murphy, R.P., 2009. Green jobs: fact or fiction? Houston: Institute for Energy Research.

Morriss, A.P., Bogart, W.T., Dorchak, A. and Meiners, R.E., 2009. Green jobs myths. University of Illinois Law \& Economics Research Paper, LE09-001. Champaign, IL: University of Illinois, Case Western Reserve University. [online] Available at: <https://scholarship.law.tamu.edu/facscholar/360> [Accessed 18 July 2018].

Pociovălișteanu, A.D., Novo-Corti, I., Aceleanu, M.I., Șerban, A.C. and Grecu, E., 2015. Employment Policies for a Green Economy at the European Union Level. Sustainability, [e-journal] 7(7), pp.9231-50. https://doi.org/10.3390/su7079231.

Pollin, R., Garrett-Peltier, H., Heintz, J. and Scharber, H., 2008. Green recovery: a program to create good jobs and start building a low-carbon economy. Washington: Political Economy Research Institute, Center for American Progress.

Poverty Environment Partnership (PEP), 2012. Building an inclusive green economy for all: Opportunities and challenges for overcoming poverty and inequality. Berlin: The Poverty Environment Partnership (PEP).

Pujaria, D., Wrightb, G. and Peattiec, K., 2003. Green and competitive. Influences on environmental new product development performance. Journal of Business Research, [e-journal] 56(8), pp.657-671. https://doi.org/10.1016/S0148-2963(01)00310-1.

Rabe, B.G., 2004. State house and Greenhouse:The Emerging Politics of American Climate Change Policy. Washington: Brookings Institution.

Ronzon, T., Piotrowski, S., M'Barek, R. and Carus, M., 2017. A systematic approach to understanding and quantifying the EU's bioeconomy. Bio-based and Applied Economics, [e-journal] 6(1), pp.1-17. http://dx.doi.org/10.13128/BAE-20567.

Russo, M.V. and Fouts, P.A., 1997. A Resource-Based Perspective on Corporate Environmental Performance and Profitability. The Academy of Management Journal, 40(3), pp.534-59.

Sillanpää, M. and Ncibi, C., 2017. A Sustainable Bioeconomy: The Green Industrial Revolution. Cham: Springer International Publishing AG.

Singh, V. and Fehrs, J., 2011. The work that goes into renewable energy. [pdf] Washington: Renewable Energy Policy Project. Available at: <http://www.globalurban.org/ The_Work_that_Goes_into_Renewable_Energy.pdf $>$ [Accessed 15 July 2018].

Steele, F., 2009. Multilevel Models for Binary Responses. Bristol: Centre for Multilevel Modelling, University of Bristol.

The Organisation for Economic Co-operation and Development (OECD), 2011. Towards green growth. [pdf] Available at: <https://read.oecd-ilibrary.org/environment/towardsgreen-growth_9789264111318-en\#page1 > [Accessed 18 July 2018]. 
The Organisation for Economic Co-operation and Development (OECD), 2017. Employment Implications of Green Growth: Linking jobs, growth, and green policies. [pdf] Available at: <https://www.oecd.org/environment/Employment-Implications-of-Green-GrowthOECD-Report-G7-Environment-Ministers.pdf> [Accessed 18 July 2018].

Țugulea, O., 2017. City Brand Personality-Relations with Dimensions and Dimensions Inter-Relations. Sustainability, [e-journal] 9(12), pp.1-22. https://doi.org/10.3390/ su9122243.

Voineagu, V., 2006. Revoluţia bioeconomică, istoria reconcilierii economiei occidentale cu biologia evolutivă. Centenarul naşterii lui Nicolas Georgescu-Roegen. [pdf] Available at: 〈http://www.insse.ro/cms/files/onicescu/Georgescu\%20Roengen.pdf> [Accessed 28 July 2018].

Wandzich, D.E. and Płaza, G.A., 2017. New and Emerging Risks Associated With "Green" Workplaces. Workplace Health \& Safety, [e-journal] 65(10), pp.493-500. https://doi.org/10.1177/2165079916674967.

Wei, M., Patadia, S. and Kammen, D.M., 2010. Putting renewables and energy efficiency to work: how many jobs can the clean energy industry generate in the US? Energy Policy, 38(2), pp.919-31.

Williams, C.C. and Horodnic, A.V., 2017. Rethinking informal payments by patients in Europe: An institutional approach. Health Policy, 121(10), pp.1053-62.

Williams, C.C. and Horodnic, A.V., 2018a. Explaining informal payments for health services in Central and Eastern Europe: An institutional asymmetry perspective. PostCommunist Economies, 30(4), pp.440-58.

Williams, C.C. and Horodnic, A.V., 2018b. Evaluating the prevalence of informal payments for health services in Southeast Europe: An institutional approach. Southeast European and Black Sea Studies, [e-journal] 18(3), pp.345-365. https://doi.org/ 10.1080/14683857.2018.1487138.

Williams, C.C. and Horodnic, I.A., 2015a. Explaining and tackling envelope wages in the Baltic Sea region: An institutional perspective. Baltic Journal of Management, 10(3), pp.295-312.

Williams, C.C. and Horodnic, I.A., 2015b. Explaining the prevalence of illegitimate wage practices in Southern Europe: An institutional analysis. South European Society and Politics, 20(2), pp.203-21.

Williams, C.C. and Horodnic, I.A., 2016. An institutional theory of the informal economy: Some lessons from the United Kingdom. International Journal of Social Economics, 43(7), pp.722-38.

Yi, H., 2013. Clean energy policies and green jobs: An evaluation of green jobs in U.S. metropolitan areas. Energy Policy, 56(3), pp.644-52. 